On the defensive
Bush administration
set to back US missile
shield
p122

\title{
Scepticism greets claims that uranium shells cause leukaemia
}

Quirin Schiermeier, Munich

This month's fierce political debate in Europe over the health hazards posed by ammunition made from depleted uranium is being met with broad scepticism from researchers. Instead, they suggest a number of potential candidates for the health problems being observed.

The argument centres on shells used in the 1999 Kosovo conflict, which were made from uranium-238, a mildly radioactive by-product from nuclear power production.

Italy, Belgium, Portugal and Sweden have each started separate investigations into the health effects of the ammunition following the discovery of six cases of leukaemia among Italian soldiers who served in Kosovo.

In response to mounting public concern, NATO says it will provide a full list of targets in Serbia and Kosovo where depleted uranium ammunition was used in attacks.

But radiation experts say that exposure to depleted uranium, which is used in ammunition on account of its very high density, would be unlikely to cause blood-based diseases such as leukaemia. The alpha radiation it emits is less intense than that from the naturally occurring element, they say.

"If anything, we would expect depleted uranium to cause lung or bone cancer, rather than leukaemia," says Manfred Paschke, head of radiation protection at a German government nuclear research laboratory in Jülich. Uranium intake is known to cause kidney damage, but the scientific literature shows no link with leukaemia.

Researchers say that the investigation of leukaemia in Kosovo veterans should not be confined to uranium. Enforcement of health and safety rules in the military during wartime are "notoriously lax", says Paschke. "The cancer risk from misuse oflubricants, solvents and disinfectants is always high," he adds.

The military, environmental and health implications of uranium-238 have been investigated since at least 1974. The US Department of Defense's latest report on the matter, published last month in response to concerns over exposure of troops during the Gulf War, finds that: "The evidence to date does not support claims that depleted uranium caused or is

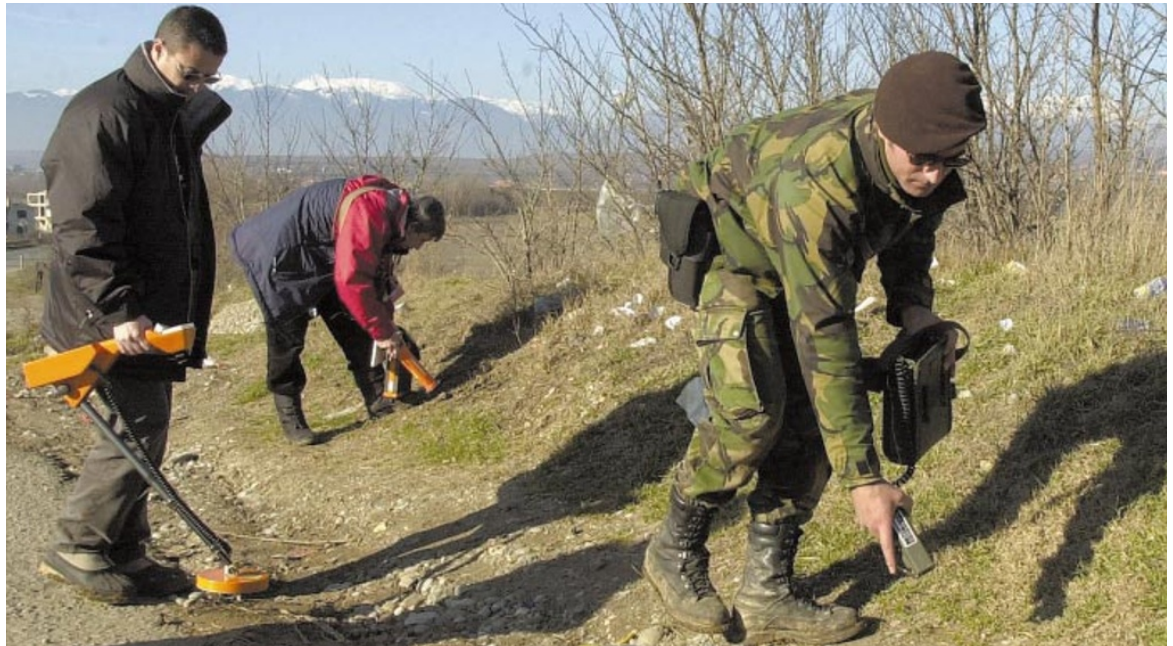

NATO's legacy? Portuguese soldiers measure radiation levels near Klina in Kosovo last week.

causing Gulf War veterans' illnesses."

Scientists believe that this also applies to Kosovo. According to press reports, only around eight tonnes of uranium-238 were released by US bombing of Serbian targets during the Kosovo war, against about 350 tonnes used in the Gulf conflict. "This is much too little for a health-sensitive large-scale contamination of the region," says Christian Küppers, a nuclear radiation expert at the Öko Institute in Darmstadt, Germany, which does environmental health research.

http://www.gulflink.osd.mil/envexp.html inttp://www.llirc.org/durs.htm

\section{Dye dispute leans Amersham's way}

\section{Declan Butler}

Rival manufacturers of automated DNAsequencing machines have clashed in a California courtroom over the intellectual property rights to the fluorescent dye used in their equipment.

According to a pretrial ruling made last week by US federal judge Charles Breyer, the dye technology used by the California-based Applied Biosystems infringes a patent held by the British company Amersham Pharmacia Biotech. The case will come to full trial later this month.

The ruling is one of several in a tit-for-tat battle over various patents and claims on sequencing technology, which began when Amersham sued Applied Biosystems in 1997 over the launch of its BigDye product.
At stake are not only the market shares of Applied Biosystem's 3700 Prism DNA analyser and Amersham's MegaBACE system, but also a slice of the glory for the sequencing of the human genome.

In a written statement in response to the pretrial ruling, Applied Biosystems said that the company "continues to believe that we will prevail". But Sir William Castell, chairman of Amersham, describes the ruling as "very significant". He adds that the onus is now be on Applied Biosystems to invalidate the pretrial ruling.

Amersham is suing Applied Biosystems for undisclosed financial damages. The trial is expected to end in February, with a 90-day period for appeals.

http://www.delphion.com/details?\&pn=US05688648 